\title{
Effects of nonionic and ionic surfactants on survival, oxidative stress, and cholinesterase activity of planarian
}

\author{
Mei-Hui Li * \\ Environmental Toxicology Laboratory, Department of Geography, National Taiwan University, 1, Section 4, Roosevelt Road, Taipei 106, Taiwan
}

Received 4 April 2007; received in revised form 23 July 2007; accepted 19 August 2007

Available online 1 October 2007

\begin{abstract}
Eight widely used surfactants (cetyltrimethylammonium bromide; CTAB, benzethonium chloride; Hyamine 1622, 4-nonylphenol; NP, octylphenol ethoxylate; Triton X-100, dodecylbenzene sulfonate; LAS, lauryl sulfate; SDS, pentadecafluorooctanoic acid; PFOA, and perfluorooctane sulfonate; PFOS) were selected to examine their acute toxicities and effects on oxidative stress and cholinesterase (ChE) activities in Dugesia japonica. The differences in acute toxicity among eight surfactants to planarians were at least in the range of three orders of magnitudes. The toxicity rank of surfactants according to estimated 48-h LC 50 was $\mathrm{SDS}>\mathrm{NP}>\mathrm{LAS}>\mathrm{Hyamine}$ $1622>$ CTAB $>$ Triton X-100 $>$ PFOS $>$ PFOA. The toxicity rank of surfactants according to 96-h LC 50 was as follows: SDS $>$ CTAB $>$ NP $>$ LAS $>$ Hyamine $1622>$ Triton X-100 $>$ PFOS $>$ PFOA. There were significant increases in catalase activities in planarians exposed to LAS at nominal concentrations of 0.5 or $1 \mathrm{mg} 1^{-1}$ and to PFOS at nominal concentrations of 5 or $10 \mathrm{mg} 1^{-1}$ after 48-h exposure. Inhibitions of $\mathrm{ChE}$ activities were found in planarians exposed to Hyamine 1622 at all concentrations tested, to PFOS at nominal concentration of $10 \mathrm{mg}^{-1}$, to PFOA at nominal concentrations of 50 or $100 \mathrm{mg}^{-1}$ and to NP at nominal concentration of $0.5 \mathrm{mg}^{-1}$. A significant increase in ChE activities was also observed in planarian exposed to Triton X-100 at nominal concentration of $5 \mathrm{mg}^{-1}$. The implication of ChE inhibition by NP, PFOS and PFOA on neurological and behavioral effects in aquatic animals requires further investigation.
\end{abstract}

(C) 2007 Elsevier Ltd. All rights reserved.

Keywords: Dugesia japonica; Lipid peroxidation; Cholinesterase activity; Antioxidant enzyme activity; Nonionic surfactants; Ionic surfactants

\section{Introduction}

Surfactants are widely used in everyday personal care and household products as well as in a variety of industrial applications. As a result, large amounts of surfactants are commonly discharged in large quantities to sewage treatment plants or directly to the aquatic environment in areas where there is no sewage treatment. In fact, many surfactants and their degradation products have been found worldwide in wastewater discharges, sewage treatment plant effluents, natural water and sediments (Ying, 2006). Because many surfactants are ubiquitous (Ying et al., 2002; Venhuis and Mehrvar, 2004), the potential toxic

\footnotetext{
${ }^{*}$ Tel.: +8862 33665839; fax: +886223622911.

E-mail address: meihuili@ntu.edu.tw
}

effects of these chemicals have attracted much research attention in the past several decades (Abel, 1974; Lewis and Suprenant, 1983; Lewis, 1991). However, previous investigations have concentrated mainly on anionic surfactants, and there is limited toxicological information on other types of surfactants or some new emerging surfactants such as 4-nonylphenol (NP), pentadecafluorooctanoic acid (PFOA), or perfluorooctane sulfonate (PFOS).

Many different mechanisms of toxicities exist for different types of surfactants and one single surfactant can produce its toxicity through more than one mechanism. In general, toxic effects of surfactants are observed via damage on gills and epidermis of aquatic vertebrate or disruption of cellular membrane of aquatic invertebrate (Abel, 1974). The toxicity of surfactants is primarily determined by the ability of the surfactants to adsorb and penetrate 
the cell membrane of aquatic organisms (Rosen et al., 2001). However, the molecular mechanisms of toxicities of surfactants are not well understood after surfactant adsorption on the membrane surface. What is known is that an interaction with lipid membranes appears to disrupt membrane integrity, thus causing toxic effects (Abel, 1974). The disruption of membrane integrity is possibly caused by interference with membrane permeability or membrane proteins. One possible mechanism of disruption of membrane integrity was oxidative stress which has detrimental effects on membrane integrity, leading to a loss of fluidity and increased ion permeability (Livingstone, 2003).

Most surfactants have an ionic or polar head group connected to a hydrophobic tail with a straight or branched hydrocarbon chain. Hydrocarbon metabolisms of surfactants by aquatic animals might be produced highly reactive oxygen species and to cause oxidative stress in organisms. Information of surfactant-induced oxidative stress in aquatic organisms is still very limited and effects of different classes of surfactants in vivo need further investigations. In addition, some studies have recently indicated that some surfactants may inhibit cholinesterase $(\mathrm{ChE})$ activity in aquatic animals (Guilhermino et al., 1998, 2000a; Garcia et al., 2000). Indeed, the chemical properties of surfactants can alter enzyme activities by binding or disrupting enzyme structure (Cserháti et al., 2002). However, most ChE inhibitions were observed in vitro experiments (Guilhermino et al., 1998; Garcia et al., 2000) but very few in vivo experiments (Guilhermino et al., 2000a). Because of their common occurrence in aquatic environment, it will be of important to examine effects of different surfactant types on ChE inhibition in aquatic animals.

Freshwater free-living planarians are distributed worldwide in unpolluted streams and an important component of the aquatic ecosystem. Traditionally, planarians have been a favored animal model in developmental biology (Newmark and Alvarado, 2002) and neuroscience research (Pagan et al., 2006). Furthermore, they have been suggested as test organisms for various types of short-term toxicity bioassays because they are sensitive to different classes of environmental pollutants (Horvat et al., 2005; Pra et al., 2005). In addition, they can be easily collected in large numbers, require only low culture and test medium volumes, and can be kept inexpensively in laboratory for toxicological testing. These characteristics make planarian a suitable organism for studying the effects of environmental pollutants in aquatic environment.

The objective of this study was to evaluate aquatic toxicity of surfactants using a freshwater planarian, Dugesia japonica, as an animal assay. Eight commonly used surfactants were selected. Their adverse toxicities on aquatic invertebrates were determined by examining the effects of these surfactants on survival, oxidative stress and $\mathrm{ChE}$ activity in $D$. japonica. These different surfactants were selected in view of their known widespread human exposure and environmental occurrence (Venhuis and Mehrvar,
2004; Lehmler, 2005). Cetyltrimethylammonium bromide (CTAB) and benzethonium chloride (Hyamine 1622) are used primarily in cosmetics and shampoos for its antimicrobial and cationic surfactant properties. Octyl phenol ethoxylate (Triton X-100) and NP are nonionic surfactants widely used in industrial and household products. Of four anionic surfactants chosen, sodium dodecylbenzene sulfonate (LAS) and lauryl sulfate (SDS) are commonly used as active ingredients in household and personal care products as well as in specialized applications, while PFOS and PFOA are two fluorinated surfactants with growing environmental concerns and are widely applied to fabrics, carpets and paper (Renner, 2005).

\section{Materials and methods}

\subsection{Chemicals}

NP was purchased from Riedel-de Haën (SigmaAldrich, USA), with a chemical purity of $94 \%$. PFOS $(>98 \%)$ was obtained from Fluka. Hyamine 1622, Triton X-100, LAS $(80 \%)$, PFOA ( $>98 \%)$, SDS $(99 \%)$ and CTAB $(99 \%)$ were obtained from Sigma-Aldrich. The properties of surfactants and the range of nominal testing concentrations for each surfactant are listed in Table 1. In this study, all stock solutions and test beakers for surfactants tested were used glass containers, except for PFOS and PFOA treatments which used polyprolene containers for stock solutions and test vessels because these two chemicals have potential to be adsorbed onto glass surface. In addition, all biochemical materials for enzyme assays were purchased from Sigma-Aldrich. HPLC grade acetone was purchased from Mallinckrodt. NP was dissolved in acetone for preparing the test stock solution. All other stock solutions for testing chemicals were prepared in dechlorinated tap water.

\subsection{Test organisms}

D. japonica was collected from Nan-shi stream located in Wu-lai, Taipei County, Taiwan in 2004. Since then, the planarians have been maintained in dechlorinated tap water at our laboratory. Animals were fed with raw chicken liver once a week. Culture medium was renewed weekly after feeding.

\subsection{Acute toxicity test}

The planarians (body length $=0.9 \pm 0.1 \mathrm{~cm}$ ) were exposed to different surfactants with at least five different concentrations or dechlorinated tap water as a control group. For each concentration, five animals were kept in $50 \mathrm{ml}$ of test solution in a beaker and each treatment was replicated five times during the experiment. All acute toxicity experiments were conducted in a temperature incubator at $25 \pm 1{ }^{\circ} \mathrm{C}$ with a $12 \mathrm{~L}: 12 \mathrm{D}$ illumination. The animals were not fed and inspected every $24 \mathrm{~h}$ for mortality during 
Table 1

Properties and tested nominal concentration range of surfactants studied

\begin{tabular}{|c|c|c|c|c|c|}
\hline Chemicals/chemical acronyms & $\begin{array}{l}\text { Type of } \\
\text { surfactant }\end{array}$ & $\begin{array}{l}\text { Molecular weight } \\
\left(\mathrm{g} \mathrm{mol}^{-1}\right)\end{array}$ & CAS No. & $\begin{array}{l}\text { Water } \\
\text { solubility }^{\mathrm{a}}\end{array}$ & $\begin{array}{l}\text { Nominal concentration } \\
\text { range }\left(\mathrm{mg} \mathrm{l}^{-1}\right)\end{array}$ \\
\hline Dodecylbenzene sulfonate/LAS & Anionic & 348.48 & $25155-30-0$ & $5-10 \mathrm{~g} \mathrm{l}^{-1}$ & $0.01-50$ \\
\hline Lauryl sulfate/SDS & Anionic & 288.4 & $151-21-3$ & $100 \mathrm{~g} \mathrm{l}^{-1}$ & $0.01-100$ \\
\hline Perfluorooctane sulfonate/PFOS & Anionic & 538.22 & $2795-39-3$ & $680 \mathrm{mg} \mathrm{l}^{-1}$ & $10-200$ \\
\hline Pentadecafluorooctanoic acid/PFOA & Anionic & 431.10 & $3825-26-1$ & $3.4 \mathrm{~g} \mathrm{l}^{-1}$ & $100-750$ \\
\hline Benzethonium chloride/Hyamine 1622 & Cationic & 448.1 & $121-54-0$ & $44.8 \mathrm{~g} \mathrm{l}^{-1}$ & $0.05-50$ \\
\hline Cetyltrimethylammonium bromide/CTAB & Cationic & 364.46 & $57-09-0$ & $15 \mathrm{~g} \mathrm{l}^{-1}$ & $0.05-50$ \\
\hline 4-nonylphenol/NP & Nonionic & 220.35 & $104-40-5$ & $4.9 \pm 0.4 \mathrm{mg} \mathrm{l}^{-1}$ & $0.15-1$ \\
\hline octylphenol ethoxylate/Triton X-100 & Nonionic & 624 & $9002-93-1$ & Miscible & $1-100$ \\
\hline
\end{tabular}

${ }^{\text {a }}$ MSDS from different manufacturers.

the entire 96-h experimental period. The organisms without detectable movement were considered dead and removed from the test solution.

\subsection{Treatments for oxidative stress and ChE inhibition studies}

The test concentration of each surfactant for examining the effects of enzyme activities was chosen according to the results of acute toxicity of the present study as well as considerations for environmental relevance. The highest test concentration for each surfactant was selected based on the highest concentration causing no mortality from $48 \mathrm{~h}$ acute toxicity studies. In all cases, two independent experiments were conducted for each surfactant and each treatment group was performed in triplicate at each experiment. Ten animals (body length $=0.9 \pm 0.1 \mathrm{~cm}$ ) per treatment group were exposed to each surfactant at three different concentrations or dechlorinated tap water as a control group for $48 \mathrm{~h}$. Antioxidant enzyme and ChE activity measurements were conducted from the same experiments whereas lipid peroxidation measurements were made in separate experiments.

\subsection{Antioxidant enzyme activity measurements}

At the end of each experiment, the medium was removed and the planarians were rinsed gently with distilled water at least three times. Then whole-body homogenates in $500 \mu \mathrm{l}$ of $0.1 \mathrm{M}$ sodium phosphate buffer ( $\mathrm{pH} 7.5$ ) containing $0.1 \mathrm{mM}$ PMSF were immediately prepared and centrifuged at $12000 \mathrm{~g}$ for $30 \mathrm{~min}$ at $4{ }^{\circ} \mathrm{C}$. The supernatants were collected and used for the assays of catalase (CAT), superoxide dismutase (SOD) and ChE. CAT activity was measured using Aebi's method (Aebi, 1984). If brief, the reaction mixture contained $50 \mu \mathrm{l}$ of enzyme extract in $950 \mu \mathrm{l}$ of $0.05 \mathrm{M}$ potassium phosphate buffer $(\mathrm{pH} 7.0)$ with $30 \mathrm{mM}$ $\mathrm{H}_{2} \mathrm{O}_{2}$. The reaction was performed at room temperature $\left(25 \pm 1^{\circ} \mathrm{C}\right)$ for $90 \mathrm{~s}$ and CAT activity was determined from the rate of $\mathrm{H}_{2} \mathrm{O}_{2}$ decrease in absorbance at $240 \mathrm{~nm}$ using extinction coefficient $39.4 \mathrm{M}^{-1} \mathrm{~cm}^{-1}$. Each assay was done in duplicate and the average of the two values was used in the final data analysis.
The SOD activity assay was based on the inhibition of nitroblue tetrazolium (NBT) reduction using the method of Beauchamp and Fridovich (1971). The reaction mixture contained $50 \mathrm{mM}$ sodium phosphate buffer $(\mathrm{pH} 7.8)$, $0.075 \mathrm{mM}$ NBT, $13 \mathrm{mM}$ L-methionine, $0.1 \mathrm{mM}$ EDTA and $0.002 \mathrm{mM}$ riboflavin with a series of samples ranging from 5 to $30 \mu \mathrm{g}$ of the enzyme extract. The mixtures were illuminated by fluorescent lamps (light intensity was 5450 lux) for $20 \mathrm{~min}$ at $25^{\circ} \mathrm{C}$. Identical solutions held in the dark served as blanks. One unit of SOD was defined as the amount of enzyme that produced a $50 \%$ inhibition of NBT reduction under assay conditions. Each assay was done in duplicate and the average of the two values was used in the final data analysis.

\subsection{ChE activity measurement}

ChE present in planarian were characterized by measuring $\mathrm{ChE}$ inhibition after in vitro incubation of planarian homogenates for $30 \mathrm{~min}$ in the presence of specific inhibitors. Three inhibitors were used, including tetraisopropyl pyrophosphoramide (iso-OMPA), 1,5-bis(4-allydimethylammoniumphenyl)pentan-3-one dibromide (BW284C51) and eserine sulfate. ChE activity was assayed immediately after incubation with inhibitors in a concentration range from $10^{-3}$ to $10^{-8} \mathrm{M}$ from three experiments. Each experiment was a pool of 100 planarians and measured in duplicate.

Measurements of ChE activity were performed using the colorimetric method of Ellman (Ellman et al., 1961) with acetylthiocholine iodide as substrate and dithiobisnitrobenzoate (DTNB) as reagent at room temperature $\left(25 \pm 1{ }^{\circ} \mathrm{C}\right)$. In brief, the reaction mixture contained $100 \mu \mathrm{l}$ of enzyme extract in $1400 \mu 1$ of $0.05 \mathrm{M}$ sodium phosphate buffer ( $\mathrm{pH} 8.0$ ) in the presence of $0.033 \mathrm{mM}$ DTNB. The reaction was triggered by addition of $10 \mu \mathrm{l}$ of $75 \mathrm{mM}$ acetylthiocholine iodide to the sample mixture. The rate of increase in optical density of the reaction medium was measured using a Hitachi UV/VIS spectrophotometer at $412 \mathrm{~nm}$ for $120 \mathrm{~s}$. Each assay was done in duplicate and the average of the two values was used in the final data analysis. Because no selective inhibitor was used in this enzymes assay, the activities measured are referred as ChE. 


\subsection{Lipid peroxidation assay}

Lipid peroxidation was assayed using a modified procedure of Buege and Aust (1978). Planarians were homogenized in $300 \mu \mathrm{l}$ of $0.15 \mathrm{M} \mathrm{KCl}$ with $0.02 \%$ BHT immediately. An aliquot of $100 \mu \mathrm{l}$ homogenate were added to $500 \mu \mathrm{l}$ of $0.8 \%$ thiobarbituric acid (TBA) in $24 \%$ trichloracetic acid (TCA). The mixture was centrifuged at $12000 \mathrm{~g}$ for $30 \mathrm{~min}$ at $4{ }^{\circ} \mathrm{C}$. Supernatants were transferred to new eppendorf tubes, heated at $95{ }^{\circ} \mathrm{C}$ for $30 \mathrm{~min}$ in the boiling water bath, then cooled in an ice bath and centrifuged at $12000 \mathrm{~g}$ for $5 \mathrm{~min}$. The absorbance of the supernatant was recorded at $532 \mathrm{~nm}$ corrected for nonspecific turbidity by subtracting the absorbance at $600 \mathrm{~nm}$. The degree of lipid peroxidation was expressed as concentration of thiobarbituric acid-reactive substances (TBARS) participating in the reaction per milligram of tissue protein. Each assay was done in duplicate and the average of the two values was used in the final data analysis.

\subsection{Protein measurement}

Total protein concentration of the homogenate was measured using Bradford's method (Bradford, 1976). A standard curve was constructed for the protein concentration of $1-12.5 \mu \mathrm{g} \mathrm{ml}^{-1}$ of bovine serum albumin. All protein measurements were performed in triplicate and the average of the three values is reported for tissue protein contents of each sample.

\subsection{Data analysis}

The nominal concentrations that were lethal to $50 \%$ of the organisms $\left(\mathrm{LC}_{50}\right)$ for each chemical at $24,48,72$ or $96 \mathrm{~h}$ were calculated using trimmed Spearman-Karber analysis with trimmed Spearman-Karber Program (version 1.5) obtained from Environmental Monitoring Systems Laboratory (USEPA, Cincinnati, Ohio). The LOAEL values (the lowest concentration producing animal mortality significantly different from the controls) and NOAEL (the highest concentration producing no mortality significantly different from the controls) were determined by Dunnett's multiple comparison procedure using the Minitab Statistical Program (version 13.2).

For comparison reasons, data were expressed as ratio of change from the respective control value (taken as 1) for ChE activities from different surfactant treatments, and were the mean $\pm \mathrm{SD}$ of six samples from two separate experiments. Although data are presented graphically as the ratio of control enzyme activities in the absence of treatments, all statistical evaluations were performed on absolute, nonreferenced data using Minitab Statistical Program (version 13.2). Data were first tested for normality with a Kolmogorov-Smirnoff test and for equality of variance with a Bartlett's test. Because some date did not meet assumptions of normality or homogeneity of variance, all statistical comparisons for enzyme activities or lipid perox- idation were performed by nonparametric Kruskal-Wallis test. If a significant result was found, Mann-Whitney U test was used to determine which treatment groups were significantly different from the controls. In all cases, $P=0.05$ was accepted to indicate statistical significance.

\section{Results}

\subsection{Acute toxicity}

There were considerable variations in $\mathrm{LC}_{50}$ values of eight surfactants to planarians. The $48-\mathrm{h} \mathrm{LC}_{50}$ values for planarians ranged from 0.36 to $536 \mathrm{mg} \mathrm{l}^{-1}$, revealing a 1489-fold difference (Table 2). The toxicity of descending order according to $48-\mathrm{h} \mathrm{LC}_{50}$ was as follows: SDS $>$ $\mathrm{NP}>$ LAS $>$ Hyamine $1622>\mathrm{CTAB}>$ Triton $\mathrm{X}-100>$ PFOS $>$ PFOA. The 96-h $\mathrm{LC}_{50}$ values for planarians ranged from 0.36 to $458 \mathrm{mg}^{-1}$, indicating a 1272 -fold difference (Table 2). The toxicity of descending order according to 96-h $\mathrm{LC}_{50}$ was as follows: $\mathrm{SDS}>\mathrm{CTAB}>$ NP $>$ LAS $>$ Hyamine $1622>$ Triton X-100 $>$ PFOS $>$ PFOA. For SDS, all mortalities occurred within the first $24 \mathrm{~h}$ of exposure and the $24-\mathrm{h} \mathrm{LC}_{50}$ was the same as the 96-h LC $\mathrm{L}_{50}$. For other surfactants, most mortalities occurred during the first $72 \mathrm{~h}$ of exposure, except for CTAB (Table 2). Among surfactants tested, SDS always had the highest acute toxicity while PFOA had the lowest toxicity to planarian at each exposure period.

The 48- and 96-h NOAEL and LOAEL values of mortalities of different surfactants for planarians in this study were summarized in Table 3 . There were no difference in the values of the NOAEL and LOAEL values of SDS, $\mathrm{NP}$ and CTAB between $48 \mathrm{~h}$ and $96 \mathrm{~h}$ of exposure. Following $48 \mathrm{~h}$ of exposure, the NOAEL and LOAEL of mortality was in the order of SDS $>\mathrm{NP}>$ LAS $>$ Hyamine $1622>$ CTAB $>$ Triton X-100 $>$ PFOS $>$ PFOA. Following $96 \mathrm{~h}$ of exposure, the LOAEL of toxicity in descending order was $\mathrm{SDS}=$ Hyamine $1622=\mathrm{CTAB}>\mathrm{NP}>\mathrm{LAS}>$ Triton X-100 $>$ PFOS $>$ PFOA, and the NOAEL was in the decreasing toxic order of $\mathrm{SDS}>\mathrm{NP}=$ Hyamine $1622=\mathrm{CTAB}>$ LAS $>$ Triton X-100 $>$ PFOS $>$ PFOA.

\subsection{Antioxidant enzyme activities}

There were significant increases in CAT activities on planarians exposed to LAS at 0.5 or $1 \mathrm{mg}^{-1}$ and to PFOS at 5 or $10 \mathrm{mg}^{-1}$ (Table 4 ). On the other hand, there were no significant changes in SOD activities exposed to any surfactant used in the present study (Table 4).

\subsection{ChE characterization}

Esterine sulfate, an inhibitor of ChEs but not of other esterases, had a strong effect on planarian ChE to less than $10 \%$ of inhibition at concentration equal or higher than $10^{-6} \mathrm{M}$ (Fig. 1). It confirmed that $\mathrm{ChE}$ activity measurement used acetylthiocholine iodide as substrate was mainly 
Table 2

Nominal concentrations of $\mathrm{LC}_{50}\left(\mathrm{mg} \mathrm{l}^{-1}\right)$ from 24 to $96 \mathrm{~h}$ for Dugesia japonica exposed to different surfactants

\begin{tabular}{|c|c|c|c|c|}
\hline \multirow[t]{2}{*}{ Chemicals $^{\mathrm{a}}$} & \multicolumn{4}{|c|}{$\mathrm{LC}_{50}\left(\mathrm{mg} \mathrm{l}^{-1}\right)$ at nominal concentrations } \\
\hline & $24 \mathrm{~h}$ & $48 \mathrm{~h}$ & $72 \mathrm{~h}$ & $96 \mathrm{~h}$ \\
\hline LAS & $6.83(5.95-7.84)^{\mathrm{b}}$ & $1.79(1.68-1.90)$ & $1.51(1.44-1.58)$ & $1.45(1.38-1.52)$ \\
\hline SDS & $0.36(0.32-0.39)$ & $0.36(0.32-0.39)$ & $0.36(0.32-0.39)$ & $0.36(0.32-0.39)$ \\
\hline PFOS & $53(49-56)$ & $25(24-27)$ & $19(18-19)$ & $17(16-18)$ \\
\hline PFOA & $548(544-552)$ & $536(528-544)$ & $519(509-530)$ & $458(427-491)$ \\
\hline Hyamine 1622 & $7.58(7.01-8.19)$ & $2.34(2.20-2.50)$ & $2.24(2.12-2.35)$ & $2.04(1.85-2.26)$ \\
\hline СТАВ & $3.16(2.94-3.42)$ & $2.83(2.50-3.20)$ & $1.63(1.27-2.09)$ & $0.45(0.34-0.60)$ \\
\hline NP & $>1$ & $0.87(0.83-0.92)$ & $0.85(0.81-0.89)$ & $0.85(0.81-0.89)$ \\
\hline Triton X-100 & $11.8(11.6-12.1)$ & $9.4(9.1-9.6)$ & $8.8(8.6-8.9)$ & $8.5(8.4-8.7)$ \\
\hline
\end{tabular}

a Actual chemical names refer to Table 1.

b Values in parentheses are $95 \%$ confidence intervals.

Table 3

Nominal concentrations of NOAEL $\left(\mathrm{mg} \mathrm{l}^{-1}\right)$ and LOAEL $\left(\mathrm{mg} \mathrm{l}^{-1}\right)$ according to mortality determined using Dunnett's test for Dugesia japonica exposed to surfactants after 48- and 96-h exposure

\begin{tabular}{|c|c|c|c|c|}
\hline \multirow[t]{2}{*}{ Chemicals $^{\mathrm{a}}$} & \multicolumn{2}{|l|}{$48 \mathrm{~h}$} & \multicolumn{2}{|l|}{$96 \mathrm{~h}$} \\
\hline & $\begin{array}{l}\text { LOAEL } \\
\left(\mathrm{mg} \mathrm{l}^{-1}\right)\end{array}$ & $\begin{array}{l}\text { NOAEL } \\
\left(\mathrm{mg} \mathrm{l}^{-1}\right)\end{array}$ & $\begin{array}{l}\text { LOAEL } \\
\left(\mathrm{mg} \mathrm{l}^{-1}\right)\end{array}$ & $\begin{array}{l}\text { NOAEL } \\
\left(\mathrm{mg} \mathrm{l}^{-1}\right)\end{array}$ \\
\hline LAS & 2 & 1.5 & 1.5 & 1 \\
\hline SDS & 0.5 & 0.25 & 0.5 & 0.25 \\
\hline PFOS & 20 & 18 & 18 & 12 \\
\hline PFOA & 500 & 450 & 450 & 400 \\
\hline Hyamine 1622 & 5 & 1 & 1 & 0.25 \\
\hline СТАВ & 1 & 0.25 & 1 & 0.25 \\
\hline NP & 0.9 & 0.75 & 0.9 & 0.75 \\
\hline Triton X-100 & 10 & 7.5 & 7.5 & 5 \\
\hline
\end{tabular}

a Actual chemical names refer to Table 1.

due to ChE activity and not to other types of esterases. BW284C51, a specific inhibitor of AChE, inhibited planarian $\mathrm{ChE}$ to less than $40 \%$ at concentrations equal to or higher than $10^{-4} \mathrm{M}$ (Fig. 1). In addition, iso-OMPA, a specific $\mathrm{BChE}$ inhibitor, did not significantly inhibit $\mathrm{ChE}$ activity in all concentrations tested, with a maximum of inhibition of $53 \%$ at $10^{-3} \mathrm{M}$. These data indicated that $\mathrm{AChE}$ and $\mathrm{BChE}$ were both presented in planarian $\mathrm{ChE}$, whereas AChE contribution to the total ChE activity in planarian was greater than $\mathrm{BChE}$ contribution.

\subsection{ChE activity}

Inhibition of $\mathrm{ChE}$ activities was found in planarians exposed to Hyamine 1622 at all concentrations tested in this study (Fig. 2). In addition, there were significant decreases in $\mathrm{ChE}$ activities in planarians exposed to PFOA at 50 or $100 \mathrm{mg}^{-1}$, to PFOS at $10 \mathrm{mg} \mathrm{l}^{-1}$, and to NP at $0.5 \mathrm{mg}^{-1}$ (Fig. 2). On the other hand, a significant increase in ChE activities was observed in planarians exposed to Triton X-100 at $5 \mathrm{mg} 1^{-1}$.

\subsection{Lipid peroxidation}

Effects of lipid peroxidation were not observed on planarians exposed to any surfactant tested at current concentrations used (data not shown).
Table 4

Antioxidant activities (mean $\pm \mathrm{SD} ; n=6$ ) in planarian exposed to different surfactants after 48 -h treatment

\begin{tabular}{|c|c|c|c|}
\hline Surfactant ${ }^{\mathrm{a}}$ & $\begin{array}{l}\text { Nominal } \\
\text { concentration } \\
\left(\mathrm{mg}^{-1}\right)\end{array}$ & $\begin{array}{l}\text { CAT activity } \\
\left(\mathrm{H}_{2} \mathrm{O}_{2} \mu \text { mol protein }\right. \\
\left.\mathrm{mg}^{-1} \min ^{-1}\right)\end{array}$ & $\begin{array}{l}\text { SOD activity } \\
\left(\mathrm{U} \text { protein } \mathrm{mg}^{-1}\right. \\
\left.\min ^{-1}\right)\end{array}$ \\
\hline \multirow[t]{4}{*}{ LAS } & 0 & $4.62 \pm 1.62$ & $1.3 \pm 0.8$ \\
\hline & 0.1 & $4.76 \pm 1.25$ & $1.4 \pm 0.6$ \\
\hline & 0.5 & $8.49 \pm 2.11^{*}$ & $1.4 \pm 0.5$ \\
\hline & 1 & $10.45 \pm 2.95^{*}$ & $1.8 \pm 0.5$ \\
\hline \multirow[t]{4}{*}{ SDS } & 0 & $11.51 \pm 1.73$ & $1.4 \pm 0.6$ \\
\hline & 0.01 & $9.17 \pm 1.80$ & $0.8 \pm 0.3$ \\
\hline & 0.05 & $10.41 \pm 1.05$ & $1.1 \pm 0.2$ \\
\hline & 0.1 & $10.73 \pm 1.07$ & $0.9 \pm 0.4$ \\
\hline \multirow[t]{4}{*}{ PFOS } & 0 & $11.51 \pm 1.73$ & $1.5 \pm 0.6$ \\
\hline & 1 & $13.39 \pm 1.99$ & $1.2 \pm 0.3$ \\
\hline & 5 & $14.85 \pm 1.22^{*}$ & $0.8 \pm 0.3$ \\
\hline & 10 & $15.33 \pm 1.44^{*}$ & $1.5 \pm 0.7$ \\
\hline \multirow[t]{4}{*}{ PFOA } & 0 & $5.43 \pm 1.54$ & $1.6 \pm 1.0$ \\
\hline & 10 & $4.40 \pm 0.84$ & $1.4 \pm 0.4$ \\
\hline & 50 & $6.50 \pm 2.91$ & $1.4 \pm 0.5$ \\
\hline & 100 & $6.45 \pm 2.16$ & $1.4 \pm 0.6$ \\
\hline \multirow[t]{4}{*}{ Hyamine 1622} & 0 & $5.43 \pm 1.54$ & $1.6 \pm 1.0$ \\
\hline & 0.1 & $6.07 \pm 1.04$ & $1.1 \pm 0.4$ \\
\hline & 0.5 & $6.25 \pm 1.71$ & $1.3 \pm 0.4$ \\
\hline & 1 & $7.14 \pm 1.40$ & $1.0 \pm 0.4$ \\
\hline \multirow[t]{4}{*}{ CTAB } & 0 & $5.62 \pm 1.24$ & $1.7 \pm 0.9$ \\
\hline & 0.05 & $5.02 \pm 1.53$ & $1.2 \pm 0.7$ \\
\hline & 0.1 & $5.07 \pm 1.56$ & $1.1 \pm 0.3$ \\
\hline & 0.5 & $7.40 \pm 2.30$ & $1.2 \pm 0.3$ \\
\hline \multirow[t]{4}{*}{ NP } & 0 & $5.27 \pm 0.74$ & $1.7 \pm 0.9$ \\
\hline & 0.05 & $4.33 \pm 1.29$ & $1.2 \pm 0.7$ \\
\hline & 0.1 & $4.85 \pm 1.79$ & $1.1 \pm 0.3$ \\
\hline & 0.5 & $5.20 \pm 1.23$ & $1.2 \pm 0.3$ \\
\hline \multirow[t]{4}{*}{ TritionX-100 } & 0 & $4.62 \pm 1.62$ & $1.3 \pm 0.8$ \\
\hline & 0.5 & $3.74 \pm 0.40$ & $0.9 \pm 0.4$ \\
\hline & 1 & $4.01 \pm 0.88$ & $1.2 \pm 0.3$ \\
\hline & 5 & $5.19 \pm 1.56$ & $0.9 \pm 0.4$ \\
\hline
\end{tabular}

Actual chemical names refer to Table 1 .

* A significant difference from the respective controls at $P<0.05$.

\section{Discussion}

The differences in acute toxicity among eight surfactants to planarians were at least in the range of three orders of magnitudes. In general, the literature indicated cationic surfactants were more toxic to aquatic organisms than 


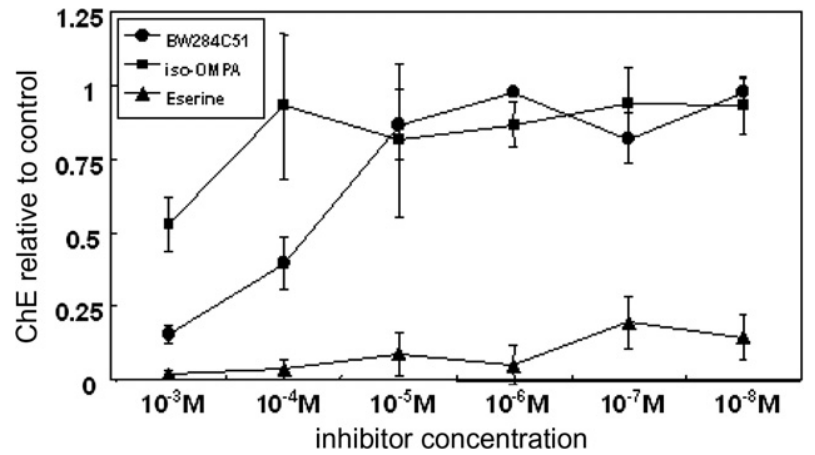

Fig. 1. In vitro effects of different inhibitors on $\mathrm{ChE}$ activities of planarian after $30 \mathrm{~min}$ of incubation with different concentrations of inhibitors. Each symbol was 4 represented data $($ mean $\pm \mathrm{SD})$ from three individual experiments using pools of 100 planarians.

anionic and/or nonionic surfactants (Lewis and Suprenant, 1983; Singh et al., 2002). However, both the most and the least toxic surfactants are anionic surfactants in the present study. In fact, the toxicity order associated with surfactant types could be dependent on an artifact of the limited number of surfactants tested rather than a real difference in relative toxicity of surfactant types (Warne and Schifko, 1999). Therefore, it might explain why no clear relationship exists between surfactant types and acute toxicity in planarians. Moreover, Daphnia magna has been suggested to be the most sensitive species to surfactants (Lewis and Suprenant, 1983; Sandbacka et al., 2000; Cserháti et al., 2002). Data on surfactant toxicity obtained from the 48-h planarian toxicity test in this study were compared with those from 48-h toxicity tests with $D$. magna in the literature. Based on these limited data (Table 5), D. japonica appears similar to $D$. magna in sensitivity to the surfactants tested.

The results of this study clearly show that the acute toxicity of SDS was considerably higher than that of other surfactants tested in D. japonica. By searching SDS ecotoxicity data on the PAN Pesticides Database (http:// www.pesticideinfo.org/Search_Chemicals.jsp), newly fertilized embryos of horse clam (Tresus capax) was the most sensitive species to SDS with a $48-\mathrm{h} \mathrm{LC}_{50}$ of $0.36 \mathrm{mg}^{-1}$. The $48-\mathrm{h} \mathrm{LC}_{50}$ of $0.36 \mathrm{mg} \mathrm{l}^{-1}$ for planarian obtained in this study also indicate that freshwater planarians have highly sensitivity to SDS among aquatic organisms tested in the literature. However, no effects were observed on planarian $\mathrm{ChE}$ or antioxidant enzyme activities at a range of 0.01 $0.1 \mathrm{mg}^{-1}$ of SDS. In fact, SDS was found to significantly inhibit the AChE activity of Mytilus galloprovincialis haemolymph at $50 \mathrm{mg}^{-1}$ or higher under in vitro condition (Guilhermino et al., 1998), or depress significantly the AChE activity of $D$. magna in vivo at concentration equal to or higher than $11.9 \mathrm{mg} \mathrm{l}^{-1}$ (Guilhermino et al., 2000a). On the other hand, no effects were found on CAT activity in the fish liver of Lateolabrax japonicus or AChE activity in the brain of L. japonicus exposed to $1 \mathrm{mg}^{-1}$ of SDS after 12 or 18 days of treatment (Wu et al., 2005). No apparent changes of planarian CAT or ChE activities
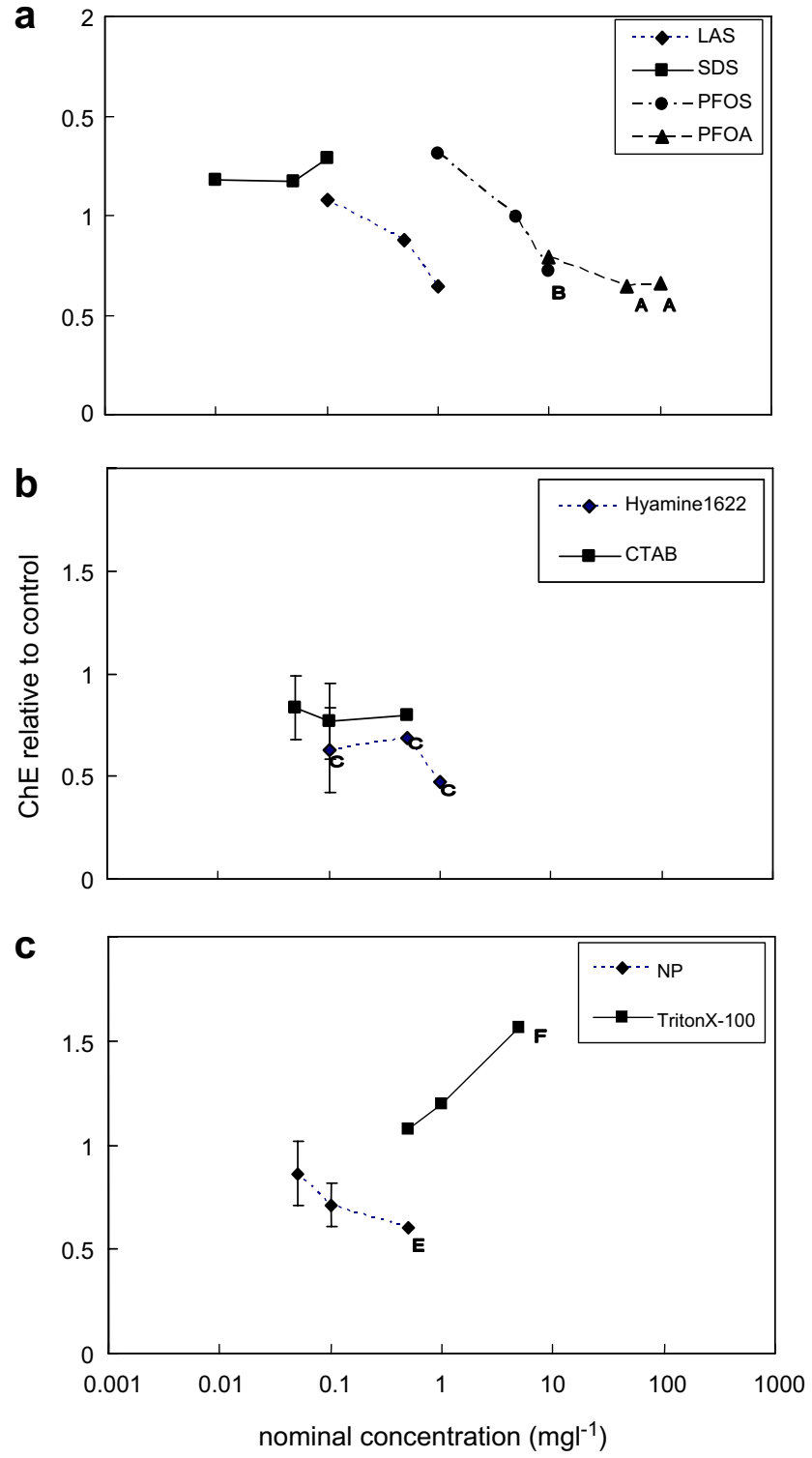

Fig. 2. ChE activities in planarian exposed to (a) anionic surfactants, (b) cationic 8 surfactants, and (c) nonionic surfactants after 48-h treatment. Values are expressed 9 as mean change from the respective control values (taken equal to 1), $n=6$. Each character is represented significantly different from the respective control group $(P<0.05)$ for each surfactant treatment.

exposed to SDS might be due to the very low concentrations $\left(0.01-0.1 \mathrm{mg}^{-1}\right)$ of SDS used in the present study.

It is well established that ChE inhibition can be used as a useful biomarker for organophosphate and carbamate pesticides both in vivo (Day and Scott, 1990) and in vitro (Hamers et al., 2000). However, several studies published in the last decade have demonstrated the possible effects of surfactants on ChE activity (Guilhermino et al., 1998, 2000a). In this study, both ionic and nonionic surfactants caused an inhibition of ChE activities. For example, a cationic surfactant, Hyamine 1622, significantly depressed $\mathrm{ChE}$ activities in planaria at nominal concentrations from 
Table 5

Comparisons of 48-h $\mathrm{LC}_{50}\left(\mathrm{mg} \mathrm{l}^{-1}\right)$ for Dugesia japonica and Daphnia magna exposed to different surfactants under static condition

\begin{tabular}{|c|c|c|c|}
\hline Surfactant ${ }^{\mathrm{a}}$ & $\begin{array}{l}48-\mathrm{h} \mathrm{LC}_{50} \\
\left(\mathrm{mg} \mathrm{l}^{-1}\right) \text { of } \\
\text { Dugesia } \\
\text { japonica } \\
\text { from this } \\
\text { study }\end{array}$ & $\begin{array}{l}\text { 48-h } \mathrm{LC}_{50} \\
\left(\mathrm{mg} \mathrm{l}^{-1}\right) \text { of } \\
\text { Daphnia } \\
\text { magna } \\
\text { from the } \\
\text { literature }\end{array}$ & Sources \\
\hline LAS & 1.79 & 9.55 & $\begin{array}{l}\text { Guilhermino et al. } \\
(2000 \mathrm{~b})\end{array}$ \\
\hline SDS & 0.36 & $6.2-9$ & LeBlanc (1982) \\
\hline PFOS & 25 & 130 & Boudreau et al. (2003) \\
\hline PFOA & 536 & 268 & Boudreau (2003) \\
\hline $\begin{array}{c}\text { Hyamine } \\
1622\end{array}$ & 2.34 & - & - \\
\hline СТAB & 2.83 & 0.05 & Knops et al. (2001) \\
\hline NP & 0.87 & 0.19 & Comber et al. (1993) \\
\hline $\begin{array}{l}\text { Triton X- } \\
\quad 100\end{array}$ & 9.4 & - & - \\
\hline
\end{tabular}

${ }^{a}$ Actual chemical names refer to Table 1.

0.1 to $1 \mathrm{mg} \mathrm{l}^{-1}$, and an anionic surfactant, PFOA, also significantly reduced planarian $\mathrm{ChE}$ activities at nominal concentrations of 50 and $100 \mathrm{mg}^{-1}$. On the other hand, one nonionic surfactant, NP, significantly decreased ChE activities in planaria at nominal concentration of $0.5 \mathrm{mg}^{-1}$ while the other nonionic surfactant, Triton X-100, significantly increased planarian $\mathrm{ChE}$ activities at $5 \mathrm{mg}^{-1}$. This result is in agreement with a previous report showing that some alkylphenolic compounds, including NP, could significantly inhibit AChE activity of rat neuronal cell line PC12 (Talorete1 et al., 2001). The immediate result of AChE inhibition is an increase in acetylcholine which may result in a decrease in cholinergic receptor number, which is a compensatory response to an acetylcholine buildup. Interestingly, Jones et al. (1998) did report that NP exposure could cause a decrease in brain muscarinic cholinergic receptors in three species of trout. However, an inhibition of ChE activity by NP in vivo system has not been published.

Inhibition of $\mathrm{ChE}$ can be mediated through the binding of the inhibitor to the catalytic site or peripheral anionic site of the enzyme (Bourne et al., 2003). In contrast to the substrate acetylcholine and to inhibitors such as organophosphate and carbamate pesticides, the chemical structure of surfactants examined in this study are lack of the molecular interaction potential of the ester group to bind in the catalytic site of the enzyme. However, surfactants might change ChE activity by binding to the anionic site of the enzyme or by changing allosteric interaction of enzyme (Cserháti, 1995; Marcel et al., 2000). In addition, it has been suggested that some surfactants could change enzyme activity by modifying the soluble AChE conformation after interaction with surfactant micelles (Guilhermino et al., 1998). In fact, molecular mechanisms for the inhibition or enhancement of ChE activity by different surfactants remain unclear and merit further studies.

\section{Conclusion}

In the present study, D. japonica showed a similar sensitivity to surfactants compared with D. magna, but revealed a distinctly different pattern of sensitivity to different surfactant types. The sensitivity of this organism to different types of surfactants serves as an ideal bioindicator of aquatic toxicity. It has been suggested that various environmental pollutants may cause oxidative stress in aquatic organisms (Livingstone, 2003). Only two anionic surfactants, LAS and PFOS, significantly increased planarian CAT activities in this study. On the other hand, there were no effects observed in planarian SOD activities or tissue concentrations of lipid peroxidation product exposed to eight surfactants at current concentrations used in this study. This result suggested that oxidative stress posed by eight surfactants might be negligible in planarians under the current test conditions. To the best of my knowledge, this is the first report showing the ChE activity inhibition by NP, PFOS and PFOA in aquatic animals in vivo. This result also supports the hypothesis that diverse classes of environmental pollutants can inhibit ChE activity in various organisms (Payne et al., 1996; Guilhermino et al., 1998, 2000a). Further mechanistic studies are needed to define how surfactants directly or indirectly change ChE activities at molecular basis. NP, PFOS and PFOA are ubiquitous environmental pollutants in the aquatic environment, therefore, the implication of $\mathrm{ChE}$ inhibition of NP, PFOS and PFOA on neurological and behavioral effects on aquatic animals warrants further investigation.

\section{Acknowledgements}

This study was supported by the National Science Council under Grant NSC 95-2313-B-002-102. The author thanks Ms. Yu-wen Chen for her assistance in enzyme activity measurements.

\section{References}

Abel, P.D., 1974. Toxicity of synthetic detergents to fish and aquatic invertebrates. J. Fish Biol. 6, 279-298.

Aebi, H., 1984. Catalase in vitro. Methods Enzymol. 105, 121-126.

Beauchamp, C., Fridovich, I., 1971. Superoxide dismutase: improved assays and an assay applicable to acrylamide gels. Anal. Biochem. 44, 276-287.

Boudreau, T.M., 2003. Toxicity of perfluorinated organic acids to selected freshwater organisms under laboratory and field conditions. MS thesis. University of Guelph, Guelph, Canada.

Boudreau, T.M., Sibley, P.K., Mabury, S.A., Muir, D.C.G., Solomon, K.R., 2003. Laboratory evaluation of the toxicity of perfluorooctane sulfonate (PFOS) on Selenastrum capricornutum, Chlorella vulgaris, Lemna gibba, Daphnia magna, and Daphnia pulicaria. Arch. Environ. Contam. Toxicol. 44, 307-313.

Bourne, Y., Tayler, P., Radic, Z., Marchot, P., 2003. Structural insights into ligand interactions at the acetylcholinesterase peripheral anionic site. EMBO J. 22, 1-12.

Bradford, M.M., 1976. A rapid and sensitive method for the quantitation of microgram quantities of protein utilizing the principle of proteindye binding. Anal. Biochem. 72, 248-254. 
Buege, J.A., Aust, S.D., 1978. Microsomal lipid peroxidation. Methods Enzymol. 52, 302-310.

Comber, M., Williams, T., Stewart, K., 1993. The effects of nonylphenol on Daphnia magna. Water Res. 27, 273-276.

Cserháti, T., 1995. Alkyl ethoxylated and alkyphenol ethoxylated nonionic surfactants interaction with bioactive compounds and biological effects. Environ. Health Perspect. 103, 358-364.

Cserháti, T., Forgacs, E., Oros, G., 2002. Biological activity and environmental impact of anionic surfactants. Environ. Int. 28, 337348.

Day, K.E., Scott, I.M., 1990. Use of acetylcholinesterase activity to detect sublethal toxicity in stream invertebrates exposed to low concentrations of organophosphate insecticides. Aquatic Toxicol. 18, 101-114.

Ellman, G., Courtney, D.K., Andres, Jr. V., Featherstone, R.M., 1961. A new and rapid colorimetric determination of acetylcholinesterase activity. Biochem. Pharmacol. 7, 88-95.

Garcia, L.M., Castro, B., Ribeiro, R., Guilhermino, L., 2000. Characterization of cholinesterase from guppy (Poecilia reticulata) muscle and its in vitro inhibition by environmental contaminants. Biomarkers 5, 274 284.

Guilhermino, L., Barros, P., Silva, M., Soares, A.M., 1998. Should the use of inhibition of cholinesterases as a specific biomarker for organophosphate and carbamate pesticides be questioned. Biomarker 3, 157163.

Guilhermino, L., Lacerda, M.N., Nogueira, A.J., Soares, A.M., 2000a. In vitro and in vivo inhibition of Daphnia magna acetylcholinesterase by surfactant agents: possible implications for contamination biomonitoring. Sci. Total Environ. 247, 137-141.

Guilhermino, L., Diamantino, T., Carolina, S.M., Soares, A.M., 2000 b. Acute toxicity test with Daphnia magna: an alternative to mammals in the prescreening of chemical toxicity? Ecotoxicol. Environ. Safety 46, 357-362.

Hamers, T., Molin, K.R.J., Koeman, J.H., Murk, A.J., 2000. A smallvolume bioassay for quantification of the esterase inhibiting potency of mixtures of organophosphate and carbamate insecticides in rainwater: development and optimization. Toxicol. Sci. 58, 60-67.

Horvat, T., Kalafatic, M., Kopjar, N., Kovacevic, G., 2005. Toxicity testing of herbicide norflurazon on an aquatic bioindicator species the planarian Polycelis felina (Daly.). Aquat. Toxicol. 73, 342-352.

Jones, S.B., King, L.B., Sappington, L.C., Dwyer, F.J., Ellersieck, M., Buckler, D.R., 1998. Effects of carbaryl, permethrin, 4-nonylphenol, and copper on muscarinic cholinergic receptors in brain of surrogate and listed fish species. Comp. Biochem. Physiol. 120C, 405-414.

Knops, M., Altenburger, R., Segner, H., 2001. Alterations of physiological energetics, growth and reproduction of Daphnia magna under toxicant stress. Aquatic Toxicol. 53, 79-90.

LeBlanc, G.A., 1982. Laboratory investigation into the development of resistance of Daphnia magna (Straus) to environmental pollutants. Environ. Pollut. 27, 309-322.

Lehmler, H.J., 2005. Synthesis of environmentally relevant fluorinated surfactants - a review. Chemosphere 58, 1471-1496.

Lewis, M.A., 1991. Chronic and sublethal toxicities of surfactants to aquatic animals: a review and risk assessment. Water Res. 25, 101-113.
Lewis, M.A., Suprenant, D., 1983. Comparative acute toxicities of surfactants to aquatic invertebrates. Ecotoxicol. Environ. Safety 7, 313-322.

Livingstone, D.R., 2003. Oxidative stress in aquatic organisms in relation to pollution and aquaculture. Revue. Med. Vet. 154, 427-430.

Marcel, V., Estrada-Mondace, S., Magne, F., Stojan, J., Klaébé, A., Fournier, D., 2000. Exploration of the Drosphila acetylcholinesterse substrate activation site using a reversible inhibitor (Triton X-100) and mutated enzymes. J. Biol. Chem. 275, 11603-11609.

Newmark, P.A., Alvarado, S.A., 2002. Not your father's planarian: a classic model enters the era of functional genomics. Nature Rev. Genet. 3, 210-219.

Pagan, O.R., Rowlands, A.L., Urban, K.R., 2006. Toxicity and behavioral effects of dimethylsulfoxide in planaria. Neurosci. Lett. 407, 274 278.

Payne, J.F., Mathieu, A., Melvin, W., Fancey, L.L., 1996. Acetlcholinesterase, an old biomarker with a new future? Field trials in association with two urban rivers and a paper mill in Newfoundland. Marine Pollut. Bull. 32, 225-231.

Pra, D., Lau, A.H., Knakievicz, T., Carneiro, F.R., Erdtmann, B., 2005. Environmental genotoxicity assessment of an urban stream using freshwater planarians. Mutat. Res. 585, 79-85.

Renner, R., 2005. Another route to PFOA. Environ. Sci. Technol. 39, $35 \mathrm{~A}$.

Rosen, M., Li, F., Morrall, S.W., Versteeg, D.J., 2001. The relationship between the interfacial properties of surfactants and their toxicity to aquatic organisms. Environ. Sci. Technol. 35, 954-959.

Sandbacka, M., Christianson, I., Isomaa, B., 2000. The acute toxicity of surfactants on fish cells, Daphnia magna and fish - a comparative study. Toxicol. In Vitro 14, 61-68.

Singh, R.P., Gupta, N., Singh, S., Sing, A., Suman, R., Annie, K., 2002. Toxicity of ionic and nonionic surfactants to six macrobes found in Agra, India. Bull. Environ. Contamin. Toxicol. 69, 265-270.

Talorete1, T.P.N., Isoda, H., Maekawa1, T., 2001. Alkylphenolic compounds and their effect on the injury rate, survival and acetylcholinesterase activity of the rat neuronal cell line PC12. Cytotechnology 36, 163-169.

Venhuis, S.H., Mehrvar, M., 2004. Health effects, environmental impacts, and photochemical degradation of selected surfactants in water. Int. J. Photoenergy 6, 115-125.

Warne, M.S.J., Schifko, A.D., 1999. Toxicity of laundry detergent components to a freshwater cladoceran and their contribution to detergent toxicity. Ecotoxicol. Environ. Safety 44, 196-206.

Wu, J., Yu, Z., Song, X., Wang, Y., Cao, X., 2005. Comparative researches on effects of sodium dodecylbenze sulfonate and sodium dodecyl sulfate upon Lateolabrax japonicus bimoarker system. Environ. Toxicol. Pharm. 20, 465-470.

Ying, G.G., 2006. Fate, behavior and effects of surfactants and their degradation products in the environment. Environ. Int. 32, 417431.

Ying, G.G., Williams, B., Kookana, R., 2002. Environmental fate of alkylphenols and alkylphenol ethoxylates - a review. Environ. Int. 28, 215-226. 